\title{
"I AM DIFFERENT FROM OTHER WOMEN IN THE WORLD" THE EXPERIENCES OF SAUDI ARABIAN WOMEN STUDYING ONLINE IN INTERNATIONAL MASTER PROGRAMMES
}

\author{
Annamaria Szilagyi [annamaria.szilagyi@ohecampus.com], Laureate Online Education, The Netherlands
}

\begin{abstract}
This paper presents findings from a qualitative study that investigated seven female Saudi Arabian students of the University of Liverpool's online Masters programmes. Qualitative, firstperson research methods and hermeneutic phenomenology were chosen for the analysis and interpretation of transcripts (Langeveld, 1983; van Manen, 1997; Creswell, 2007, Roth, 2012). The principles of cultural anthropology (Hall \& du Gay, 1996; Hannerz, 1992; Lull, 2001; Coleman, 2010) were used to take a snapshot of the interviewees' particular world to provide an overview of the Saudi Arabian culture where the role of women is at the centre of academic, political, religious and social debate These findings reflect the participants' everyday lives, identities, values and beliefs, presented in a self-reflective, personal 'life-world' story of one single Saudi Arabian woman. The findings demonstrate that the primary motivators in choosing online international education to further study are existing limitations of travelling to a university campus and customary gender-segregated education in Saudi Arabia. As a contrast, international online education offers the opportunity to gain up-to-date research-based knowledge in their chosen profession, learn critical thinking and problem solving skills and communicate with male and female students from different cultures.
\end{abstract}

Keywords: gender-based segregation, international online education, adult learning phenomenology, cultural anthropology, Saudi Arabia

\section{Introduction}

"There was no possibility of taking a walk that day."

(Brontë, C., 1847, Jane Eyre, p.9.)

Education in The Kingdom of Saudi Arabia (hereafter referred to as KSA) is segregated in all levels. The education system is controlled by religious authorities that restrict women's access to education and limit their participation in certain professions. Therefore, women's choices are limited to certain professions or employment. They are not allowed to study engineering, journalism, pharmacy or architecture, as these professions are traditionally considered male activities (Cordesman, 2003). Women study mainly in the fields of health care, education, and public administration (AlMunajjed, 1997; Baki, 2004).

Structure and content of education in KSA is heavily influenced by the ulama, Muslim scholars who have decision making power primarily on religious questions, which controls culture, educational curriculum and structure of the educational system. The ulama have particularly strong control over the education of women and their role in the society (Prokop, 2003, Jamjoom, 2010). Although this authority resists the increasing presence of women in the labour market, more and more women are pursuing graduate studies. In fact, more than 63 percent of students in Saudi Arabian universities are female. This number indicates the government's long term strategy to invest in female higher education despite of the cultural restrictions: except one 
university in the country, each institution has facilities for segregated education where women are allowed to study, but the subjects in their programmes are more limited than those dedicated to men (Hamdan, 2005). Most of these women are enrolled in education, humanities or social sciences and live mostly in Jeddah and the Western Provinces, which are more exposed to globalization and international education (Doumato, 1992; Prokop, 2003; Onsman, 2011).

This article will present the particular 'life-world' of seven female, emancipated Saudi Arabian students who are eager to learn and actively participate to change the status-quo of women in the Saudi Arabian society by pursuing alternative higher education. Online learning lifts the restrictions on their physical mobility and alleviates their forced segregation in the Saudi Arabian society. The life of a Saudi Arabian female student, studying in an online, Western European University, uncovers new dimensions in her experience with new paradigms to help find her own way to succeed.

\section{Women and gender-based segregation in KSA}

In the Arab world, KSA is one of the most conservative Muslim countries, considered the keeper of the Islamic religion (Baki, 2004). Islamic studies are a core component of the educational curricula, in which male and female students learn their rights, obligations and duties (Denman \& Hilal, 2011; Jamjoom, 2010). This religious education treats genders differently due to the different roles men and women assume in the Saudi Arabian society: boys are traditionally taught about male activities, girls about their role as mothers and housewives (Baki, 2004).

The traditional interpretation of the role of women in the Saudi Arabian society is based on the Qur'an, and the Wababi interpretation of Islam, which is one of the most orthodox religious authorities within the Islamic religion. "The Qur'an gave women equal but not identical rights with men on personal, civil, social and political levels [...] and warned that the mixing of sexes could lead to seduction and evil consequences that might follow". (Baki, 2004, p.2) In terms of clothing, the Wababi interpretation calls for modest clothing for women including covering the face. The Qur'an also mentions modest clothing of women; although there is no indication about covering the face (Yamani, 1996; Almunajed, 1997; Baki, 2004).

Female seclusion was intended originally to protect women, but the orthodox interpretation of the Holy Qur'an created a "socially extreme concept of female modesty" (Onsman, 2011, p.223). The segregation of women is applied everywhere in the society. Whilst men are free to go anywhere, women are not allowed to travel within the country or abroad without the written permission of their close male relatives. Women are not allowed to drive or use public transportation without the presence of a male guardian. If they use public transportation, they have a separate entrance and can only use the designated seats at the back of the vehicle (Baki, 2004). The source of segregation and restriction in clothing lies in the strong belief that the chastity of a woman and the honour of the family are inseparable. (Baki, 2004; Prokop, 2003) The social structure reinforces this belief by keeping women in limitations in order to prevent them losing the family honour (Mackey, 2002). Although today the Saudi Arabian educational system offers female education from primary to doctoral level, the restrictions in mobility create a significant obstacle for women to freely access higher education, since in order to attend a class on campus or go to a public (segregated) library, they need to employ a chauffeur or ask a close male family member to drive them to and from the institution (Baki, 2004).

The first university exclusively for women (Princess Noura Bint Abdul Rahman University) was founded in Riyadh in 2010. Although the opening of new institutions exclusively for female students (and staff) facilitates women's access to higher education, it also continues to reinforce gender segregation. Despite international academia remains critical about gender segregation in 
Saudi Arabian higher education, Saudi Arabian society is unlikely to support gender desegregation due to its "religious inappropriateness" (Onsman, 2011, p.524). KSA is facing the challenge of achieving international recognition and a competitive edge in higher education, while keeping conservative cultural norms. In order to maintain the international ranking and elevate the international status of Saudi Arabian higher education, the Ministry of Education approved the first mixed-gender private university (King Abdullah University for Science and Technology) in 2009. The religious police has no power at this institution, women are allowed to study together with men, as well as drive and uncover their head on campus grounds (Onsman, 2011).

\section{Online Education in KSA}

A major challenge of the Saudi Arabian educational system is to meet the demands of the growing student population and provide higher educational services though the institutions cannot absorb the number of students applying for studies. Internet has been publicly available in the country since 1999; the number of users increased dramatically from 200,000 in 2000 to 6.4 million in 2007 (Alebaikan \& Troudi, 2010; Hamdan, 2014). For this reason, the Saudi Arabian Ministry of Higher Education is promoting the use of online and blended learning methods at their universities: the National Plan for Information Technology was established in order to finance the National E-learning and Distance Learning Centre founded in 2006. This centre provides technical support for the development of online delivery methods and content for higher education in KSA (Alebaikan \& Troudi, 2010).

Responding to women's demand for de-segregation, Saudi Arabian universities have attempted to facilitate women's access to higher education since the '90's by using online delivery methods. Videoconferencing at King Saud University has allowed Saudi Arabian female students to attend a male class without meeting face-to-face or having any conversation with male peers (Nakshabandi, 1993; Mackey, 2002). This method of learning, however, has not particularly been successful due to the lack of group discussion and female participation (Baki, 2004).

An increasing number of Saudi Arabian institutions use learning management systems, such as Blackboard, WebCT, Tandarus (an Arabic learning management system) to facilitate online learning (Alebaikan \& Troudi, 2010). King Abdulaziz University in Jeddah was the first university to offer online Bachelor's degree programmes and in 2007, Imam Muhamed Bin Saud University offered the first distance learning programmes with instructions entirely online (Alebaikan \& Troudi, 2010). By 2013, most of the higher educational institutions included online or blended learning components in their curricula (Hamdan, 2014). International institutions and local branches of foreign universities in KSA offer online or blended courses in undergraduate levels in English (Alebaikan \& Troudi, 2010; Onsman, 2011). Al-Fahad's study (2010) conducted on female learners' satisfaction regarding online learning at King Saud University confirmed that although students felt more isolated, they appreciated the flexibility that e-learning provided, i.e. not having to travel to the institution. They also liked that the online course was focused on the interests of learners, something they have not experienced in the traditional Saudi Arabian learning environment. As of 2011, more than 20,000 Saudi Arabian students are enrolled in online BA or MA programmes (Hamdan, 2014). In the first quarter of 2015 the total number of Saudi Arabian students enrolled in Saudi Arabian universities are 669,271, from which 248,343 are male and 420,928 are female (Saudi Arabian Ministry of Higher Education, 2015).

As the educational system experiences change, the position of the Saudi Arabian Ministry of Education is ambiguous in relation to international online programmes: it does not fully accept qualifications from purely online programmes due to concerns about the quality of the online programme (Hamdan, 2014). On the one hand, KSA promotes the development of online or 
blended learning methods and English teaching in order to sponsor the education of skilled Saudi Arabian citizens with English proficiency (Moores-Abdool, Yahya \& Unzueta, 2009). On the other hand it also recognises the culturally invasive power of low cost mass media (internet, satellite television, social media) and that native English teachers in international programmes may pose cultural challenges for Saudi Arabian students due to their different ways of thinking and interacting (Onsman, 2011).

One of the challenges in implementing online or blended learning is that Saudi Arabian public universities are used to the traditional didactic, lecture-based, teacher-centred education. Their curricula are often out-dated or irrelevant to students' career paths. In addition, they continue to use memorization and passive learning practices (Alebaikan \& Troudi, 2010; Hamdan, 2014). Hamdan's study (2014, p.312.) describes that in the Saudi Arabian school system, knowledge and truth are fixed concepts and "what is taught in school is unquestionable", which does not facilitate the development of critical thinking skills or the appreciation of diversity. As opposed to this, online learners in KSA have free access to educational resources, online libraries, online forums that facilitate intercultural communication between students from all over the world and with the other gender as well. "This unprecedented openness to new educational resources and cultural perspectives is leading KSA's younger generations to become less traditional and strict in their views" (Hamdan, 2014, p.310).

\section{Methodology}

The findings are part of a wider research project that focuses on the online learning experience of Saudi Arabian students and follows phenomenological principles (van Manen, 1997; Crotty, 1998; Creswell, 2007; Mason, 2012; Roth, 2012) in the research design. For this particular article, the indepth, semi-structured interviews with seven Saudi Arabian female students were used to enable the investigation of their 'life-world' (Langeveld, 1967, 1983).

Hermeneutic phenomenology, which is oriented towards life experience by interpreting the 'texts' of life was used to interpret the narratives of the interview participants (van Manen, 1997). The rigour of phenomenological and first-person research methods did not allow me to create or add any new texts to what the participants had actually said. Derida's "there-is-no-outside-text"approach was strictly followed when describing the phenomena (Derida in Roth, 2012, p.5).

The data generation process provided in-depth narratives, monologues and self-reflections of Saudi Arabian women about their everyday lives; rich textual descriptions about the phenomenon, which led to deeper reflection and multi-layered understanding of their online learning experience (Smith, 1997, Ajjawi \& Higgs, 2007). The chosen research method helped to understand the intimate world of adult women living in KSA.

The interviewees were all enrolled in or graduated from the online master programmes of the University of Liverpool delivered by Laureate Online Education. The selected students were all Saudi Arabian citizens and had at least one year of learning experience in the online programme. A group of female students was selected, with a range of passing grades, to understand their views of learning online in a global environment.

After the researcher had received the ethical approval from the University of Liverpool, students were asked to sign a consent form which informed them about the aims and objectives of the research, the structure of the interview and that their answers would be recorded. They were asked to choose whether they preferred to be interviewed by a male or female researcher. They all preferred to talk to a female interviewer. The semi-structured interviews were organized either face-to-face or via Skype. 
Participants were between 25 and 49 years of age; their religion is Islam. Most of them have had some educational experience in America or Western European countries; one has also experienced online education in a US university. Table 1 presents further details about the interview participants.

Table 1: Data of interview participants

\begin{tabular}{|l|l|l|l|l|}
\hline Student & Residency & Age & Programme & Previous studies in higher education \\
\hline Student 1 & Riyadh & 33 & $\begin{array}{l}\text { MSc in Human Resource } \\
\text { Management }\end{array}$ & $\begin{array}{l}\text { American University, US, Associated } \\
\text { Degree in Health Promotion }\end{array}$ \\
\hline Student 2 & Makkah & 47 & $\begin{array}{l}\text { MSc in International } \\
\text { Management }\end{array}$ & $\begin{array}{l}\text { College of Education in Makkah, } \\
\text { Bachelor of Arts \& Education, English } \\
\text { Language and Literature }\end{array}$ \\
\hline Student 3 & Khobar & 27 & $\begin{array}{l}\text { MSc in International } \\
\text { Management (Health } \\
\text { Specialization) }\end{array}$ & $\begin{array}{l}\text { Lakehurst University, BA in } \\
\text { Management Information System }\end{array}$ \\
\hline Student 4 & Riyadh & 47 & $\begin{array}{l}\text { MSc in International } \\
\text { Management (Health } \\
\text { Specialization) }\end{array}$ & King Saud University, BA in Nursing \\
\hline Student 5 & Jeddah & 25 & $\begin{array}{l}\text { MSc in Human Resource } \\
\text { Management }\end{array}$ & $\begin{array}{l}\text { King Abdul Aziz University, BA in } \\
\text { Business Administration }\end{array}$ \\
\hline Student 6 & Jeddah & 49 & $\begin{array}{l}\text { MSc, in International } \\
\text { Management }\end{array}$ & $\begin{array}{l}\text { King Abdul Aziz University, BA in } \\
\text { Business Administration }\end{array}$ \\
\hline Student 7 & Jeddah & 32 & $\begin{array}{l}\text { MSc in Human Resource } \\
\text { Management }\end{array}$ & $\begin{array}{l}\text { King Abdul Aziz University, BA in English } \\
\text { Language and Literature }\end{array}$ \\
\hline
\end{tabular}

The interview structure focused on three main topics: cultural values at home, online learning experience (MA level) and face-to-face learning experience in the Saudi Arabian segregated higher educational system (BA level). The interview protocol covered a set of questions that invited students to reflect upon their culture and online learning challenges.

The interviews were transcribed and analysed with rigorous phenomenological and first- person research methods (Langeveld, 1983; Hycner, 1985; Ajjawi \& Higgs, 2007; Roth, 2012). The transcripts were coded in NVivo and the eventual bracketing phase started with the identification of units of meanings categorized in themes and sub-themes. Following Langeveld's $(1967,1983)$ 'life-world' studies, the findings are narrated in first person singular to present the inner world of these seven female, Saudi Arabian students linked in one single narrative as if it was the selfexploratory journey of one single Saudi Arabian woman. Nothing has been changed or added to their original narratives, only stylistic and grammar mistakes were corrected in order to make the story more coherent.

Continuous self-reflection, cultural self-awareness, regular consultation with experienced researchers in phenomenology and cultural studies as well as frequent cross-checks with the critical literature ensured faithfulness to the data. 


\section{Findings}

\section{Limitations on Accessibility}

"Women don't drive here, so we use drivers or a male family member has to drive us (Student $1,3,4,5,6,7) ”$

My name is Layla, I am from Saudi Arabia and it was not possible for me to 'take a walk. that day'. There is no possibility of driving for women in this country. Saudi Arabia is one of the developing countries...so we still aren't like...people who live in London or the US or any other place. It is all about people and how they think about women driving a car. I think this is not a religious but a political issue. "(Student 1)

'The University had a bus service for female students, but my father didn't want me to use it. There is no public transportation for women; it is only for men. Mainly non-Saudi citizens use it, because they don't have a car. Most of the Saudis have their own cars. It's not common to use the public transportation; it is not really good for ladies at all. Sometimes we feel scared, and it is not appropriate for us. We could use taxi, but taxis are not safe either, not all the taxi drivers are good people." (Student 5) "Women cannot move freely because if they do so, they might be under threat or sexual barassment." (Student 6)

'Women don't drive here, so we use drivers or a male family member has to drive us. Women bere usually bave three different ways to find someone to drive them. Either it is one of the male family members, like brother, husband, father or nephew who can drive or they have their private drivers with contract. Private drivers are usually from Indonesia, India, Pakistan, Bangladesh and the Philippines." (Student 4)

"That day I ended up using our private driver. I am privileged because my family can afford a private driver. I' don't feel good about this. It seems that things are slowly changing and I bope that within the upcoming five years I will have the chance to drive." (Student 5)

"The doors of the University are locked once you are in." (Student 4)

"When I studied on campus during my graduate studies, my dad used to drive me to the University. My first class started at 7 am. He could not come to pick me up before 5 pm, due to his work commitments. I was not allowed to go out before the end of the academic day, even if I had no classes in between. The doors of the University are locked once you are in. At the beginning this was very strange for me, but then I got used to it.

That day the library was closed for female students. We shared the library with the male University and it was available for us only on specific days. Since then the schedule has changed and the library is more available for ladies now, but that time I wished I had an online library without restricted hours for women. In fact, during my online studies, I liked the online library: I could get there any time, day or night. I found it very easy and handy to have the online library, because whenever I needed it, I just logged in and searched for articles or the subjects I needed." (Student 4)

"That day I spent most of the time in the canteen of the University. I tried to study for the next day without too much success, as I left at home most of my books. I felt a bit intimidated after this first class; the professor was quite formal and not so belpful." (Student 5) "When I studied in the US for a short time, the instructor was always on the spot to help when I asked a question. It was a long day, but I understood there is no way out 
of here. My father came at $5 \mathrm{pm}$ to pick me up: he showed his ID and said that he came for me. I was called to prepare to leave and the door was suddenly open. That was the first time we had a conversation about finding more suitable ways of learning for me." (Student 1)

\section{Social Restrictions}

"I am different than other women in the world" (Student 3)

"I am different than other women in the world. I'm getting knowledge, I join companies to work but still I am treated differently and I have fewer rights than other women. The Saudi culture is very strict and conservative; a religion-based culture. It is a man-dominant society. There are a lot of things that are not allowed for women.

I don't have the same opportunities and I am not allowed to be myself, because the culture is not supporting women. When making decisions, a woman has to check first how it is acceptable and permitted by the religion. It does not matter how educated, broad-minded and intelligent you are, as a female. In fact, officially I can't make decisions on my own; I have to go back to my father or husband to help me making a decision. In reality I make quite a lot of decisions on my own: I am leading a female unit in a hospital and my experience as a manager for ladies so far, has been a smooth journey without too many troubles. I think that the most challenging is to be a leader for a male team, because Saudi men don't accept women to manage or lead them." (Student 3)

"When I had to decide my career path, I had to take into account that there are specific professions I cannot study, such as engineering. There was a time when women's job applications were rejected purely due to their gender: there were very strict rules about accepting women in companies and in non-medical fields. Employers did not care about the knowledge or experience applicant women had; they were not accepted because the company thought, extra fees are involved in employing women and they had the belief that women did not know how to work. Things are slowly changing and now I am more accepted based on my education and knowledge. But it is still a struggle." (Student 3)

"It's a struggle to work as a woman" (Student 4)

"Usually women in Saudi Arabia choose to be teachers or nurses. Recently, we can work in 'female' banks, or in the airport, in the female sections only. For example, when a nurse graduates, she is given the choice to work in paediatric units, where she deals with babies and their mothers only, or in mixed area, where she takes care of men and women. Most of the nurses will choose to work with women or children only.

I finished my graduate studies in nursery, which I've completed partly in the US and in Saudi Arabia. I am enrolled in the MSc in International Management programme of the University of Liverpool, in Health specialization, and I have just completed my dissertation. I work now as a supervisor in a hospital, in Paediatrics and my unit consist in female nurses. I couldn't manage male staff: they cannot tolerate having a woman as a supervisor. It's a struggle to prove myself because I have to show constantly that women can do as much as men do. Even if professionals accepted this fact and they worked with me as an equal, it's difficult for the parents. Sometimes they come and say: 'Can we talk to a man? Do you have a man here that we can talk with?' They don't want to feel that a woman gives them the information, and makes the decision for them. Usually they are the decision makers, without the help of a woman. It is difficult to deal with them, as sometimes we have very conservative and religious parents. 
When I communicate difficult news to a mother, normally I close the door of the office to bave some more privacy; I sit close to the mother, hold her hands, touch her shoulder and hug her if she is very emotional. But I can't do this with a man, of course. I am conscious that I cannot just close the door and be alone with the father only. If I need privacy, I have to close the door, and I need a third person sitting with me in the same room. I have to sit in a certain distance from the father, use specific tone of voice, so he will not feel offended or perceive that I give orders to bim. I cannot talk to him in my usual tone of voice, which is a bit higher; I can't smile, I can't put make-up because I know men look at these things.

When I had less experience, a parent complained about me. He said that I was not respectable because of the way I talked and because I was sitting too close to him'. I was focusing on delivering more information about the child care and provide as much support as I could in an emotionally difficult situation. As there was no one else in the room, no one believed me: it was only my word against his. At the end I've got an official warning. After all, I started to have doubts about my own judgement: everyone in my environment told me that I should have not behaved disrespectfully, even though they were not in the room and did not hear the conversation. I've started to believe that I was indeed disrespectful, but I did not notice at that time." (Student 4)

"I learnt that no matter what my intentions are, parents' opinion is more important. I have to be conservative as far as my appearance and behaviour." (Student 1) "Now I am prepared that when I talk to a father, I have to ask a staff member to witness the conversation, change the way I sit, my posture, my body language, my tone of voice, even the way I think. It is so difficult... I am trying my best to behave differently, because I know this is the only way that I can provide good care to my patients and to their parents. I don't mind doing the extra miles just to make them feel comfortable, safe and secured with me." (Student 4)

"I don't feel bad when I cover my bair" (Student 5)

"Being a Muslim woman it means that I have to wear my bijab. It is a restriction of my religion. In our religion women are different than men, not in a bad way, as we are equal. Using the scarf in Saudi Arabia, which we call hijab means protection and that I can express my religion better than anywhere else. I have to cover myself, my body and my head when I go out. As we are Muslims we believe that women, who cover themselves in this life, will reach the paradise in their next life. So this is a good encouragement for me, it's a good incentive. Actually I feel very good and proud of being a Muslim woman, wearing hijab, because I feel protected and I know I gain benefits for my next life.

If you see a man without hair, you can accept his face and you don't care about the hair. But if you asked a man, what is the first thing he looks at a woman, he would say: if the woman doesn't have hair, I don't look at her'. Our God asks us to cover our hair...in order to protect us." (Student 5) "We believe that covering the hair will not make us very appealing to men and that we have a very conservative religion that we protect. We always cover the hair and wear conservative clothing, no arm can be shown, no legs can be shown, so it becomes less appealing to men." (Student 1) "This is our belief about cover and this is how you protect yourself and you protect also men, from not seeing you actually." (Student 1 and Student 5)

"I have a lot of friends who are better Muslim than I am and they put their veil also abroad. We are very proud to put our veil because we love to express our thoughts, our opinion, and our religion. It does not distract us from learning, from riding a car; it does not distract us from anything. Why didn't I put it, when I lived in America? I'm a lasy Muslim. I'm 
raised in a bit more open family: covering wasn't so strict. So that makes me lary to put it on. But I didn't wear, for instance, bathing suit when I went to swim in the US. I swam with long pants. Why is that? Because my culture tells me that I should not wear short bathing suit when I swim." (Student 1)

When I was younger and not married, as a Muslim girl I was not allowed to have a boyfriend.

"Any man who was not my uncle, my father or my brother, was a foreign man for me. I believe that if a man looks at me, when I'm covering my hair and wearing good and covered clothes, he cannot think about me in a bad way. He has to respect me and this is the point. Respect means he cannot think about me in a sexual way. The first thing they think about all the time is sex. In our religion men have to cut their imagination when they start to think about these things. I don't think they do, but I am not so sure actually about this area. They have to fight with themselves, which is not easy at all. Even for woman it is not easy, but we try.

Not all the Saudis are the same. As my family is less conservative sometimes they allowed me to go out with my male friends. My relationship with my male friends was formal. We were not allowed to talk about everything as I did with my girlfriends and my parents always had to give their approval, when I went out with a male friend."(Student 5)

\section{Impact of gender status on learning}

"I could not communicate with male students face-to-face, but I could use network communication" (Student 5)

"During my bachelor studies in Saudi Arabia male students were separated in other classes. I could not communicate with them face-to-face, but I could use network communication. I used to communicate with them during my studies. This way of communication is not so different than communicating with men in the online master programme: you don't see them, but you can see them interact by exchanging messages and words." (Student 5) I treated the online classroom, as if there was no actual communication with men, there were only responses on the subject. I read their answers for the discussion question and I wrote a response, but usually there were no emails, there was no further connection. (Student 7) There were situations when there was disagreement in the online class, but it wasn't difficult for me to deal with it. I just posted my opinion and discussed it with them back and forth. Whenever I discussed it, of course, we never talked outside the class because we're not at that level of relation. (Student 5)

"I didn't feel connected with online students" (Student 4)

"I didn't have close relationship with my classmates. I only imagined them. I didn't see them in real life." (Student 5) "The time I spent online was enough for my own learning, but did not increase my relationship with my classmates." (Student 1) "Even if we had the opportunity to exchange emails or occasionally called each other, still the face-to-face relation was not there, and I always felt there was something missing. I read their posts and got the idea but their expressions and feelings were missing." (Student 4) "In the online class you were given materials and all depended on you. In contrast, in the face-to-face university I was more dependent on the instructor and not on myself, because I could ask bim on the spot." (Student 3) 
"I wanted to change the way I was educated: I wanted to open my mind to other cultures, experience research-based learning and increase my knowledge" (Student 1, 2, 3, 4)

"When my family moved to the US due to my father's work, I studied a year on campus in the US. It was active learning because I met different people every day and talked with them regularly. We expressed our thoughts verbally, not only by writing. It gave me a lot of motivation." (Student 1) "In the US, we had open communication with the instructors on spot, and they explained the subject in the classroom, if there were questions." (Student 3)

"Then we moved back to Saudi Arabia and I wanted to continue with my studies in master level. Saudi universities would accept some credits for courses that I took in the US. But the educational system here is very difficult: it is the old and traditional way of teaching and learning. Professors have formal relationship with students and sometimes I avoided them because I didn't like their way of teaching." (Student 5) "Students were not dependent on themselves, everything was ready for them. I remember that when I had a Biology class during my $B A$ studies, the professor came with notes that were ready for us, we read them, completed the assignment, passed the exam and that was it. There was notbing about teaching students how to use their brains, search in the library for extra books and articles. This is exactly what is happening in other Universities outside Saudi Arabia. I am used to the American style of education and the Arabic education wouldn't be satisfactory for me. This is why I wanted to change the way I was educated." (Student 1, 2, 4)

"I chose the online master programme of the University of Liverpool because I wanted to open my mind to other cultures, experience research-based learning and increase my knowledge." (Student 1, 2, 3, 4) "Online learning gave me the opportunity to meet people from different cultures, with different believes and knowledge." (Student 3)

"In the online class we were free to speak" (Student 4)

"I had experience with other online courses at an American online university. At the time there were lots of political issues between the Middle East and the States after 9/11 and I felt discriminated in the class. I was the only student from the Middle East and the professors were really against me. They were irrational and very critical about my postings, so I had to quit. My experience with the University of Liverpool is totally different. I really liked studying here and I've recommended the University for many people. There was respect towards students and between students. No one commented on anything that might burt or make others uncomfortable in the class. In my culture, usually we don't discuss things openly, but in the online classes we were free to speak. No one joked about whatever I posted or said." (Student 4) "I didn't feel I was judged by my background or my religion. It was very easy and comfortable to express my thoughts on religion, education and my cultural background. It was a respectful environment." (Student 1) "That is something really good about Liverpool." (Student 4) 


\section{Discussion}

The constructed "story" of a Saudi Arabian woman provides a snapshot of the transforming reality of female Saudi Arabian students. It portrays the everyday difficulties of travelling back and forth to the campus of the university or to a public library due to customary limitations on women's mobility. It also demonstrates how Saudi Arabian women view gender segregation, the essence of modest clothing or covering their hair, and also sheds light on culturally acceptable ways of communicating with the other gender. The struggle of how women learn to communicate with men in order to be accepted and appreciated in their own cultural milieu is evident from their recounts. In the world of Saudi Arabian women, restrictions are completely acceptable and justified, as they were created to protect them. Yet, the interviewees are evidently ambitious Saudi Arabian women who are aware of how differently other women are treated in other parts of the world. They have similar career aspirations and dreams of self-fulfilment which motivate them to look for different ways of learning.

Online education provides a way to lift cultural limitations. Female students enjoy that they are free to talk and communicate with male students within the classroom, although most of them would not initiate further discussion with them outside of the class. This alternative was commonly accepted by the participants. They felt that online learning not only gave them a chance to increase their knowledge about different cultures, but also helped them to use different methods of learning in order to develop critical thinking skills and adapt new problem solving methods. Similarly to Hamdan's (2014) studies the findings demonstrated that online learning helped students become self-disciplined, self-motivated, engaged and autonomous learners who own their learning process. This is significantly different from the use of passive learning or memorization techniques practiced in the local universities within the constraints of segregated education. Hamdan (2014) and Moores-Abdool et al (2009) and Al-Fahad (2010) also confirm that Saudi Arabian female students appreciate international online or blended education because of these features. Through online learning female students become more independent and active in search of alternatives ways of learning that are more suitable for their individual needs.

Online course developers, policy makers, instructors and study counsellors, who develop and deliver online courses for culturally diverse groups of students, should be aware of the different cultural needs of their diverse student population and may require constant cultural training to keep up-to-date their cultural knowledge about their students. Similarly to other researches conduced in this field, the findings of this paper suggest that Saudi Arabian female students may need more training than their Western peers to adjust to the progressive, constructivist educational methods applied in international online programmes (Hamdan, 2014; MooresAbdool et al, 2009; Al-Fahad, 2010). Due the their unfamiliarity with interactive learning in online, multicultural classrooms with mixed genders, they need clear guidelines regarding the code of conduct in class including rules of communication with peers and instructors and Western academic integrity norms. They will benefit from more support in developing their time management, self-study and critical thinking skills. Additional technical support and culturally sensitive university policies need to be implemented that respect the social restrictions in their local environment and their limitations on class or internet accessibility. Culturally sensitive approaches applied in each level of their studies will keep these students engaged long term in the online international programmes. 


\section{Conclusion}

The findings of this paper demonstrated the awareness of female Saudi Arabian students of their ambiguous role as women in the Saudi Arabian society: on the one hand they are trying to fulfil the cultural expectations of the conservative Saudi Arabian society, whereas on the other hand, they are eager to take an active role in their education and career choices. This paper demonstrated culture and country specific motivational factors, leading them to look for alternative learning methods and it also shed light on the limitations that determine their everyday lives and learning experiences. These women choose online learning in international programmes because it eliminates cultural and physical boundaries, opens a new horizon, allows free communication between male and female students from different cultures and also provides a way to gain up-to-date knowledge in specific professions.

The internationalization of education is a widespread and irreversible process generated by globalization. (Al-Fahad, 2010; Hamdan, 2014) It has led to the emergence of young, female professionals within KSA who are hungry for social recognition in their cultural milieu, and are willing to take an active role in the socio-cultural and political changes, protesting against the restrictions imposed on them within their own country. The surrounding Muslim society insists on the practice of gender segregation; women's appearance in the male sphere is deemed provocative and offensive and women are restricted to "spend most of their lives in veil and in the four walls of their house". (Syed, 2010, p.151) There are still relatively few studies conducted on the effects of international online education that enters 'their house' and at the same time, opens up virtually the whole world at least for the duration of their studies. The present paper highlights that more research is needed in this area and also suggests that policy makers in KSA should take action in order to create more clarity in what is considered a role model for today's women in KSA. The serious potential of highly educated women, who are just as skilled as their male colleagues, should also be recognized in the Saudi Arabian labour market.

The ambitious goal of the KSA to elevate the international status quo of its higher education continuously opens up the debate on gender-based segregation, which still remains unresolved and contested (Prokop, 2003; Baki, 2004; Osman, 2011). In the course of their emancipation, the female Saudi Arabian society has to compete with foreigners in the labour market, having up-todate knowledge and excellent English language skills, and also, with the Saudi Arabian male population. They have to face conservative political forces that insist on the idea of gender segregation in order to secure employment opportunities for the members of the male society (Doumato, 1992; Prokop, 2003). Therefore, the question remains: how are these ambitious and skilled female students going to find suitable jobs (given their degrees) in the male-dominant Saudi Arabian society, where the same limitations that forced them to choose online learning in international programmes as opposed to in-country face-to-face education still exist and determine the everyday life of a working woman? Will they ever be treated just like their male colleagues, i.e. as equals? This study does not aim to answer this rhetorical question, as the educational, religious and socio-political debates around the role of women in the Saudi Arabian society are yet to crystallize. It does, however, intend to raise awareness regarding the ambiguous situation of educated Saudi Arabian women: as students they learn the way "other women" (Student 4) learn in Western societies, but their life is connected to a socio-cultural milieu that resists giving them equal human rights. 


\section{Reference}

1. Ajjawi, R. and Higgs, J. (2007). Using Hermeneutic Phenomenology to Investigate How Experienced Practitioners Learn to Communicate Clinical Reasoning. In The Qualitative Report, 12(4), (pp. 612-638).

2. Alebaikan, R. and Troudi, S. (2010). Blended Learning in Saudi Universities: Challenges and Perspectives. In ALT-J, Research in Learning Technology, 18(1), (pp. 49-59).

3. Al-Fahad, F. (2010). The learners' satisfaction toward online e-learning implemented in the College of Applied Studies and Community Service, King Saud University, Saudi Arabia: Can E-learning Replace the Conventional System of Education? In Turkish Online Journal of Distance Education-TOJDE, 11(2), (pp. 61-72).

4. AlMunajjed, M. (1997). Women in Saudi Arabia Today. London: Macmillan.

5. Alquraini, T. (2010). Special Education in Saudi Arabia: Challenges, Perspectives, Future Possibilities. In International Journal of Special Education, 25(3), (pp. 139-147).

6. Alwadie, A. (2013). Online Continuing Medical Education in Saudi Arabia. In Performance Improvement, 24-28.

7. Anderson, T. (2008). Theory and Practice of Online Learning ( $2^{\text {nd }}$ ed.). Canada: Marquis Book Printing.

8. Baki, R. (2004). Gender-segregated education in Saudi Arabia: Its impact on social norms and the Saudi Labor market. In Education Policy Analysis Archives, 12(28).

9. Bronte, C. (2006). Jane Eyre. London: Penguin Classics.

10. Bruner, J. (1996). The Culture of Education. Cambridge, MA: Harvard University Press.

11. Colaizzi, P. (1978). Reflection and research in psychology: A phenomenological study of learning. Dubuque, IA: Kendall/Hunt.

12. Coleman, W.D. (2010). Cultural Autonomy. Frictions and Connections. Vancouver, Toronto: UBC Press.

13. Cordesman, A.H. (2003). Saudi Arabia Enters the Twenty-First Century. Connecticut: Praeger.

14. Creswell, J. (2007). Qualitative Inquiry \& Research Design. Choosing Among Five Approaches. Thousand Oaks, London, New Delhi: Sage.

15. Crotty, M. (1998). The foundation of social research: Meaning and perspective in the research process. Sidney, New South Wales, Australia: Allen \& Unwin.

16. Denman, B.D. and Hilal, K.T. (2011). From barriers to bridges: An investigation on Saudi student mobility (2006-2009). In International Review of Education, 57, (pp. 299-318).

17. Doumato, E. (1992). Gender, monarchy and national identity in Saudi Arabia. In British Journal of Middle Eastern Studies, 19(1), (pp. 31-47).

18. Glasze, G. and Alkhayyal, A. (2002). Gated housing estates in the Arab world: Case studies in Lebanon and Riyadh, Saudi Arabia. In Environment and Planning B: Planning and Design, 29, (pp. 321-336).

19. Hall, S. and du Gay, P. (eds.) (1996). Questions of Cultural Identity. London, Thousands Oaks, New Delhi: Sage.

20. Hamdan, A. (2005). Women and Education in Saudi Arabia: Challenges and Achievements. In International Education Journal, 6(1), (pp. 42-64). 
21. Hamdan, A. (2014). The Reciprocal and Correlative Relationship between Learning Culture and Online Education: A Case from Saudi Arabia. In The International Review of Research in Open and Distance Learning, 15(1), (pp. 310-336).

22. Hannerz, U. (1992). Cultural complexity: Studies in the social organization of meaning. New York: Columbia University Press.

23. Hycner, R. (1985). Some guidelines for the phenomenological analysis of interview data. In Human Studies, 8, (pp. 279-303).

24. Jamjoom, M. (2010). Female Islamic Studies teachers in Saudi Arabia: A phenomenological study. In Teaching and Teacher Education, 26, (pp. 547-558).

25. Langeveld, M.J. (1967). The Stillness of the Secret Place. In M.J. Langeveld \& LangeveldBakker, T.J. (eds.), Scholen maken mensen: de bijdrage der school tot de vorming van het kind. Purmerend.

26. Langeveld, M. (1983). The Secret Place in the Life of the Child. In Phenomenology + Pedagogy, 1(2), (pp. 181-191).

27. Lull, J. (2001). Culture in the communication age. London: Routledge.

28. Mackey, S. (2002). The Saudies: Inside the Desert Kingdom. New York: W.W. Norton \& Company.

29. Mason, J. (2012). Qualitative Researching ( ${ }^{\text {nd }}$ ed.). London: Sage.

30. Moores-Abdool, W.; Yahya, N. and Unzueta, C.H. (2009). Learning Preferences of Saudi University Students with Native English Speaking Teachers. Kingdom of Saudi Arabia Association of Language Teachers (KSAALT), (pp. 2-18). Al-Khobar.

31. Nakshabandi, A. (1993). Videoconferencing: King Saud University (Saudi Arabia). In International Journal of Instructional Media, 20(2), (pp. 127-136).

32. Nel, B. (1973). The phenomenological approach to pedagogy. In Journal of Phenomenological Psychology, 3(2), (pp. 201-215).

33. Onsman, A. (2011). It is better to light a candle than to ban the darkness: government led academic development in Saudi Arabian universities. In Higher Education, 62, (pp. 519-532).

34. Prokop, M. (2003). Saudi Arabia: The Politics of Education. In International Affairs Royal Institute of International Affairs 1944 - ), 79(1), (pp. 77-89).

35. Roth, W.M. (2012). First-Person Methods: Toward an Empirical Phenomenology of Experience. Rotterdam, Boston, Taipei: Sense Publisher. BIBLIOGRAPHY \l 1033

36. Saudi Ministry of Higher Education (2015). Study in KS A. Accessed on $11^{\text {th }}$ April 2015, available at http://www.mohe.gov.sa/en/studyinside/Pages/default.aspx

37. Syed, J. (2010). A historical perspective on Islamic modesty and its implications for female employment. In Equality, Diversity and Inclusion: An international Journal, 2(29), (pp. 150-166).

38. Van Manen, M. (1997). Researching lived experience: buman science for an action. London: The Althouse Press.

39. Van Manen, M. (2007). Phenomenology of Practice. Phenomenology \& Practice, 1(1), 11-30.

40. Yamani, M. (1996). Feminism and Islam: Legal and Literary Perspectives. Ithaca Press. 